\title{
CHARACTERISTIC FEATURES OF ADOLESCENTS WITH DIFFERENT CLINICAL FORMS OF CEREBRAL PALSY
}

\author{
Nataliia Melekh
}

Melekh Nataliia

LLC "Kozyavkin International Rehabilitation Clinic", Pomiretska Street 37, Truskavets, 82200, Lviv Region, Ukraine

slavychn@gmail.com; ORCID ID: 0000-0002-6898-2093

The purpose of the study is to explore the characterological features of adolescents with cerebral palsy with various nonpsychotic mental disorders of residual organic origin.

A psychodiagnostic examination of 73 adolescents with various clinical forms of cerebral palsy, who were diagnosed with nonpsychotic mental disorders of residual organic origin, was carried out: in 31 (42.5\%) - mild cognitive impairment, 42 (57.5\%) - organic emotionally labile disorder.

The study used psycho-diagnostic technique "Pathocharacterological diagnostic questionnaire" of A.E. Lichko, that intended to determine the types of accentuations of character and variants of constitutional psychopathy, psychopathic development, and organic psychopathy in adolescence and youth (14-18 years).

All adolescents underwent rehabilitation using Intensive Neurophysiological Rehabilitation System (INRS) in the Kozyavkin International Rehabilitation Clinic (Ukraine, Truskavets). The survey was conducted in the first three days of being adolescents in the rehabilitation center.

The results of the study indicate that in $100 \%$ of examined adolescents with cerebral palsy, various types of character accentuations were diagnosed. In adolescents with mild cognitive impairment, labile (29.0\%), epileptoid (24.2\%), sensitive (16.1\%), and astheno-neurotic (12.9\%) types are prevailed. In adolescents with organic emotionally labile disorder, the most commonly diagnosed types are epileptoid (22.1\%), sensitive (21.0\%), hysteroid (17.4\%), and labile (14.3\%) types. In the group of adolescents with mild cognitive impairment (F06.7), a labile type of character accentuation was diagnosed significantly more frequently $(p<0.05)$ in boys $(36.9 \% \pm 10,0 \%)$ than in girls $(6.25 \% \pm 12,0 \%)$.

The study made it possible to establish the characterological features of personality development and emotional disorders in adolescents with cerebral palsy and to predict their importance in the formation of psychopathological disorders and the quality of socio-psychological adaptation of these groups of patients.

Key words: cerebral palsy, adolescents, characteristic features. 


\section{Introduction}

It is known that emotional disturbances in adolescence are significant risk factors for the formation of persistent personality abnormalities in adults. In this context, the scientific literature practically did not receive proper coverage of the question of the general laws of personality development and emotional disorders with cerebral palsy. As we know, adolescence is considered to be one of the most difficult stages of personality formation, characterized by intensive transformations in the entire psychic sphere of a teenager: the intensive development of strong-willed traits, the active formation of self-awareness and self-esteem, the construction of a hierarchy of value orientations, and the development of one's own worldview. Describing the positive changes inherent to the psychic formation of a teenager, most researchers emphasize both the unevenness, spasmodic development of a number of these properties, and a certain disharmony that is characteristic even for a normally passing teenage period.

In addition, in adolescence, a tendency to behavioral reactions, which are usually characteristic of a younger age, is often preserved: the reaction of rejection, opposition, protest, the reaction of imitation and hypercompensation. These reactions can be presented in behavioral variants, both normal for a given age period, and pathological, not only leading to social maladaptation, but also often requiring medical and psychological correction.

There are quite numerous groups of adolescents with cerebral palsy who do not have apparent mental disorders, decreased intelligence, and behavioral deviations. These contingents of patients can be trained in general education programs in public schools. However, in such adolescents, mental development proceeds against the background of an existing disease and is often abnormal, disharmonious, i.e. there is one or another variant of dysontogenesis. Such children and adolescents have the so-called "light", "minimal" cognitive impairment, which can make schooling difficult. Accordingly, emotional and personality disorders can also contribute to the social maladaptation of these groups of patients [1, 2].

In childhood and adolescence, there is a more distinct connection than in adults, of certain forms of neurotic disorders with certain accentuations of character. Among the personality traits that contribute to the emergence of a neurotic way of responding in adolescents, V.V. Kovalev names such pathological character traits as anxious suspiciousness, increased inhibition, a tendency to form various fears and apprehension, the emergence of mental infantilism, demonstrativeness, and hysteroidity [3].

According to modern views, special importance in the pathogenesis of borderline neuropsychiatric disorders and non-psychotic behavior disorders belongs to premorbid personality traits, in particular, character accentuations [3]. The issues of socio-psychological rehabilitation of adolescents with residual non-psychotic mental disorders that have formed against the background of cerebral palsy are important. To effectively solve the problems of rehabilitation of these groups of patients, it is necessary to take into account the characterological and pathocharacteristic features that are forming in them.

\section{The purpose of the article}

To study the characterological features of adolescents with cerebral palsy with various non-psychotic mental disorders of residual organic origin.

\section{Methods used during research}

The study included 73 adolescents aged 14 to 17 years ( 42 boys and 31 girls) with various clinical forms of cerebral palsy, who were diagnosed with nonpsychotic mental disorders of residual organic origin, namely, mild cognitive impairment (F06.7) and organic emotionally labile disorder (F06.6).

Depending on the nature of the leading psychopathological disorders, all examined adolescents were divided into 2 groups. The first group included 31 (42.5\%) persons whose mental state corresponded to mild cognitive impairment (F06.7 according to ICD-10 criteria). The second group consisted of 42 (57.5\%) adolescents with organic emotionally labile disorder (F06.6). It must be emphasized that the level of intellectual development of the examined adolescents corresponded to the norm options.

Spastic diplegia (G80.1) occurred in 28 patients (38.4 $\%)$, spastic hemiplegia (G80.2) in 23 (31.5\%) (including right-sided hemiparesis in 11 patients $(15,2 \%)$, left-side hemiparesis in 12 (16.4\%), dyskinetic form (G80.3) in 12 (16.4\%), ataxic form (G80.4) in 4 (5.4\%), mixed form (G80.8) - in 6 (8.2\%).

All adolescents underwent rehabilitation using Intensive Neurophysiological Rehabilitation System (INRS) in the Kozyavkin International Rehabilitation Clinic (Ukraine, Truskavets) [4]. The survey was conducted in the first three days of being adolescents in the rehabilitation center.

To determine the types of character accentuations, the psycho-diagnostic technique "Pathocharacterological diagnostic questionnaire" was used. Pathocharacterological diagnostic questionnaire (PDQ) of A.E. Lichko [5] is intended to determine the types of accentuations of character and variants of constitutional psychopathy, psychopathic development, and organic psychopathy in adolescence and youth (14-18 years). The questionnaire consists of 25 sets of statements characterizing the basic conditions of the body and social attitudes of the person. Each set contains from 
10 to 19 answers offered to the test subject, from which he needs to choose the most characteristic and uncharacteristic for him

Using PDQ, the following types of psychopathies and character accentuations can be diagnosed: hyperthymic, cycloid, labile, astheno-neurotic, sensitive, psychasthenic, schizoid, epileptoid, hysteroid, volatile, conformal. There are also mixed types, namely: intermediate, in which the combinations are endogenous, and amalgam, which are formed during life due to the accumulation of traits of one type on the endogenous nucleus of another under adverse social and psychological conditions.

PDQalsomakesitpossibletoobtainanumber of additional indicators: index $B$ (brain minimal damage), indicating the possibility of a change in character as a result of residual organic brain damage; conformity; emancipation reaction; psychological propensity for alcoholism and delinquency; indicator of masculinity - femininity; the presence of signs of the possible development of psychopathy, discordance of character, social maladaptation.

Mathematical and statistical data processing was carried out using the method of establishing the probability of differences (according to the criteria of $\varphi$ - Fisher, $U$ Mana-Whitney, T - Wilcoxon and $\mathrm{t}$ - Student). Processing of the data obtained as a result of the study was carried out using the SPSS 15.0 for Windows software package.

\section{Results and discussion}

The results of the study indicate that in $100 \%$ of examined adolescents with cerebral palsy, various types of character accentuations were diagnosed. The general picture of accentuations was characterized by a sufficient variety: all types were noted except cycloid (Table 1).

The table shows that there were no significant differences in the frequency of occurrence of one or another type of accentuation depending on the nosological form. In the group of adolescents with mild cognitive impairment (F06.7), labile $(29.0 \% \pm 8.0 \%)$, epileptoid $(24.2 \% \pm 8.0$ $\%)$, sensitive (16.1\% $\% 7.0 \%$ ) and astheno-neurotic (12.9 $\% \pm 6.0 \%$ ) circle accentuations are prevailed.

Among F06.6 patients, character accentuations were distributed as follows: epileptoid (22.1 \% $\pm 6.3 \%)$, sensitive $(21.0 \% \pm 6.0 \%)$, hysteroid $(17.4 \% \pm 6.0 \%)$, labile (14.3\% $\% 6.0 \%)$ types.

It should be noted that the epileptoid type of character accentuations occurred in groups of adolescents with cerebral palsy with approximately the same frequency, while the astheno-neurotic and labile types were more often, but without significant differences, diagnosed in patients with mild cognitive impairment, and the hysteroid and sensitive types in a group of teenagers with an organic emotionally labile disorder. It is these character accentuations due to the severity of traits such as sensitivity, self-doubt, increased fatigue, irritability, a tendency to hypochondria, are the premorbid background on which psychogenic disorders are quite easily formed.

In the group of adolescents with mild cognitive impairment (F06.7), a labile type of character accentuation was diagnosed significantly more frequently $(p<0.05)$ in boys $(36.9 \% \pm 10,0 \%)$ than in girls $(6.25 \% \pm 12,0 \%)$.

Table 1 shows that mixed types of characteraccentuations were diagnosed in $32.3 \% \pm 8.0 \%$ of adolescents with mild cognitive impairment (F06.7) and in $45.2 \% \pm 8.0 \%$ of adolescents with organic emotionally labile dysfunction (F06.6).

In both groups, the intermediate types prevailed ( $60.0 \% \pm 16.0 \%$ and $73.7 \% \pm 10.0 \%$, respectively). The most common labile-astheno-neurotic, schizoid-epileptoid, epileptoid-hysteroid types of character accentuations.

Table 1

\section{The structure of character accentuations of adolescents with cerebral palsy (according to PDQ technique)}

\begin{tabular}{|c|c|c|c|c|}
\hline \multirow{3}{*}{ Type of accentuation } & \multicolumn{4}{|c|}{ Groups of patients } \\
\hline & \multicolumn{2}{|c|}{$\begin{array}{l}\text { Mild cognitive impairment ( } F \text { 06.7) } \\
\qquad n=31\end{array}$} & \multicolumn{2}{|c|}{$\begin{array}{l}\text { Organic emotionally labile disorder (F06.6) } \\
\qquad n=42\end{array}$} \\
\hline & Absolute number & $\% \pm m$ & Absolute number & $\% \pm m$ \\
\hline Astheno-neurotic & 4,0 & $12,9 \pm 6,0$ & 2,0 & $4,8 \pm 3,0$ \\
\hline Hyperthymic & 1,0 & $3,2 \pm 3,0$ & 1,0 & $2,4 \pm 2,0$ \\
\hline Labile & 9,0 & $29,0 \pm 8,0$ & 6,0 & $14,3 \pm 6,0$ \\
\hline Conformal & 0,0 & $0,0 \pm 3,0$ & 3,0 & $7,1 \pm 4,0$ \\
\hline Schizoid & 0,0 & $0,0 \pm 3.0$ & 1,5 & $3,6 \pm 1,5$ \\
\hline Psychasthenic & 0,5 & $1,6 \pm 3,0$ & 3,0 & $7,1 \pm 4,0$ \\
\hline Hysteroid & 3,0 & $9,7 \pm 5,0$ & 7,3 & $17,4 \pm 6,0$ \\
\hline Epileptoid & 7,5 & $24,2 \pm 8.0$ & 9,3 & $22,1 \pm 6,3$ \\
\hline Sensitive & 5,0 & $16,1 \pm 7,0$ & 8,8 & $21,0 \pm 6,0$ \\
\hline Volatile & 1,0 & $3,2 \pm 3,0$ & 0,0 & $0,0 \pm 2,0$ \\
\hline Cycloid & 0,0 & $0,0 \pm 3,0$ & 0,0 & $0,0 \pm 2,8$ \\
\hline Mixed & 10,0 & $32,3 \pm 8,0$ & 19,0 & $45,2 \pm 8,0$ \\
\hline
\end{tabular}


Amalgam mixed types were detected in $40.0 \% \pm$ $16.0 \%$ of adolescents with mild cognitive impairment (F06.7) and in $26.3 \% \pm 10.0 \%$ of patients with organic emotionally labile disorder. As it is known, amalgam types are formed as a result of the stratification of traits of one type on the endogenous nucleus of another due to improper upbringing or other long-acting factors, as well as due to the development of hypercompensatory and pseudocompensatory mechanisms [104].

The prevailing were the hyperthymic-hysteroid and labile-hysteroid types of accentuations, in which hysteroid traits are layered on the initial emotional lability or on a hyperthymic basis.

Discordance, disharmony of character was significantly more often $(p<0.05)$ observed in patients with organic emotionally labile disorder $(58.1 \% \pm 8.0 \%)$, while in the group of adolescents with F06.7 this symptom occurred in $38.7 \% \pm 9.0 \%$ of cases. Such signs of discordance prevailed: the severity of sensitive traits in the diagnosis of epileptoid and hysteroid types of character accentuation, sensitive and psychasthenic traits against the background of a pronounced reaction of emancipation and hyperthymic type.

Signs indicating the probability of psychopathy formation were observed in $48.4 \% \pm 9.0 \%$ of adolescents with mild cognitive impairment (F06.7) and in $50.0 \% \pm$
$8.0 \%$ of patients with organic emotionally labile disorder. No significant differences were found for this indicator.

A pronounced emancipation reaction was predominant in all adolescents with cerebral palsy and was recorded with a frequency of $41.9 \% \pm 9.0 \%$ in the group of patients with mild cognitive impairment (F06.7) and $47.6 \% \pm 8.0 \%$ in the group with organic emotionally labile disorder. There were no significant differences in terms of conformity. All adolescents with a maximum frequency recorded moderate conformity $(54.8 \% \pm 9.0 \%$ and $47.6 \% \pm 8.0 \%)$.

\section{Conclusions}

Character accentuations occurred in $100 \%$ of examined adolescents with cerebral palsy. In adolescents with mild cognitive impairment, labile (29.0\%), epileptoid (24.2\%), sensitive (16.1\%), and astheno-neurotic (12.9\%) types are prevailed. In adolescents with organic emotionally labile disorder, the most commonly diagnosed types are epileptoid (22.1\%), sensitive (21.0\%), hysteroid (17.4\%), and labile (14.3\%) types.

Thus, the study made it possible to establish the characterological features of adolescents with cerebral palsy and to predict their importance in the formation of psychopathological disorders and the quality of sociopsychological adaptation of these groups of patients.

\section{REFERENCES}

1. Kozyavkin V.I., Shestopalova L.F., Podkorytov V.S. Detskie cerebralnye paralichi. Mediko-psihologicheskie problemy [Child Cerebral Palsy. Medical and psychological disorders.]. Ukrainski technolohii, Lviv, 1999, 133 p. (In Russ.)

2. Kovalev V.v. Semiotika i diagnostika psihicheskih zabolevanij u detej i podrostkov [Semiotics and diagnosis of mental disorders in children and adolescents.]. Medycyna, M., 1985, 227 p. (In Russ.)

3. Kalizhnyuk E.S. Psihicheskie narusheniya pri detskih cerebralnih paralichah [Mental disorders associated with cerebral palsy.]. Vishcha shkola, Kiev, 1987, 269 p. (In Russ.)
4. Sistema intensivnoj nejrofiziologicheskoj reabilitacii: metod Kozyavkina. Posobie reabilitologa / Pod red. V.I. Kozyavkina [Itensive neurophysiological rehabilitation system: Koziavkin's method. Rehabilitation manual. Edited by V.I. Kozyavkin.]. Papuga, Lvov, 2012, 240 p. (In Russ.)

5. Lichko A.E. Psihopatii i akcentuacii haraktera u podrostkov [Psychopathy and accentuation of character in adolescents.]. Medicina, L., 1983, 256 p. (In Russ.)

\section{ЛИТЕРАТУРА}

1. Козявкин В.И., Шестопалова Л.Ф., Подкорытов В.С. Детские церебральные параличи. Медико-психологические проблемы. - Львів: «Українські технології», 1999. - 133 c.

2. Ковалев В.В. Семиотика и диагностика психических заболеваний у детей и подростков. - М.: Медицина. - 1985. - 227 с.

3. Калижнюк Э.С. Психические нарушения при детских церебральных параличах. Киев: «Вища школа», 1987. - 269 с.
4. Система интенсивной нейрофизиологической реабилитации: метод Козявкина. Пособие реабилитолога / Под ред. В.И. Козявкина. - Львов: «Папуга», 2012. -240 C.

5. Личко А.Е. Психопатии и акцентуации характера у подростков. - Л.: Медицина. - 1983. - 256 с.

\section{ХАРАКТЕРОЛОГІЧНІ ОСОБЛИВОСТІ ПІДЛІТКІВ З РІЗНИМИ КЛІНІЧНИМИ ФОРМАМИ ДИТЯЧОГО ЦЕРЕБРАЛЬНОГО ПАРАЛІЧУ}

\section{Мелех \\ Наталія Володимирівна}

ТОВ «Міжнародна реабілітаційна клініка Козявкіна», вул. Помірецька 37,

м. Трускавець, 82200, Львівська обл., Україна

slavychn@gmail.com; ORCID ID: 0000-0002-6898-2093 
Проведено психодіагностичне дослідження 73 підлітків з різними клінічними формами ДЦП, у яких було діагностовано непсихотичні психічні розлади резидуально-органічного генезу у 31 (42,5\%) - легкі когнітивні порушення, у 42 $(57,5 \%)$ - органічні емоційно лабільні порушення.

В ході дослідження використовувалася психодіагностична методика - «Патохарактерологічний діагностичний опитувальник» А.Е. Личко, який призначений для визначення типів акцентуації характеру і варіантів конституційних психопатій, психопатичного розвитку і органічних психопатій в підлітковому і юнацькому віці (14-18 років).

Всі підлітки проходили курс реабілітації за допомогою (IHР в Міжнародній реабілітаційній клініці Козявкіна (Україна, м. Трускавець). Обстеження проводилося в перші три дні перебування підлітків у реабілітаційному центрі.

Результати дослідження показали, що акцентуації характеру мали місце у 100\% досліджуваних підлітків з ДЦП. У підлітків з легкими когнітивними порушеннями переважали акцентуації лабільного (29,0 \%), епілептоїдного (24,2 \%), сенситивного (16,1 \%) та астено-невротичного (12,9\%) типів. У пацієнтів з органічними емоційно лабільними порушеннями частіше діагностувалися епілептоїдний $(22,1 \%)$, сенситивний $(21,0 \%)$, істероїдний $(17,4 \%)$ і лабільний $(14,3$ \%) типи. В групі підлітків з легкими когнітивними порушеннями (F06.7) достовірно частіше $(\mathrm{p}<0,05)$ діагностувався лабільний тип акцентуації характеру у хлопців (36,9\% $\pm 10,0 \%)$, ніж у дівчат $(6,25 \% \pm 12,0 \%)$.

Проведене дослідження дозволило встановити характерологічні особливості розвитку особистості і емоційних розладів у підлітків з ДЦП та прогнозувати їх значення у формуванні психопатологічних порушень і якості соціально-психологічної адаптації цих груп пацієнтів.

Ключові слова: дитячий церебральний параліч, підлітки, характерологічні особливості.

\section{ХАРАКТЕРОЛОГИЧЕСКИЕ ОСОБЕННОСТИ ПОДРОСТКОВ С РАЗНЫМИ КЛИНИЧЕСКИМИ ФОРМАМИ ДЕТСКОГО ЦЕРЕБРАЛЬНОГО ПАРАЛИЧА}

Мелех

Наталия Владимировна
000 «Международная реабилитационная клиника Козявкина», ул. Помирецкая 37, г. Трускавец, 82200, Львовская обл., Украина slavychn@gmail.com, ORCID ID: 0000-0002-6898-2093

Цель исследования - изучение характерологических особенностей подростков больных на ДЦП с различными непсихотическими психическими расстройствами резидуально-органического генеза.

Проведено психодиагностическое обследование 73 подростков с различными клиническими формами ДЦП, у которых были диагностированы непсихотические психические расстройства резидуально-органического генеза: у 31 $(42,5 \%)$ - легкое когнитивное расстройство, у 42 (57,5\%) - органическое эмоционально лабильное расстройство.

В ходе исследования использовалась психодиагностическая методика - «Патохарактерологический диагностический опросник» А.Е. Личко, который предназначен для определения типов акцентуаций характера и вариантов конституциональных психопатий, психопатических развитии и органических психопатий в подростковом и юношеском возрасте (14-18 лет).

Все подростки проходили курс реабилитации с помощью СИНР в Международной реабилитационной клинике Козявкина (Украина, г. Трускавец). Обследование проводилось в первые три дня пребывания подростков в реабилитационном центре.

Результаты исследования показали, что акцентуации характера имели место у 100 \% обследованных подростков с ДЦП. У подростков с легким когнитивным расстройством преобладали акцентуации лабильного (29,0 \%), эпилептоидного $(24,2 \%)$, сензитивного $(16,1 \%)$ и астено-невротического $(12,9 \%)$ типов. У пациентов с органическим эмоционально лабильным расстройством чаще всего диагностировались эпилептоидный $(22,1 \%)$, сензитивный $(21,0 \%)$, истероидный $(17,4 \%)$ и лабильный (14,3\%) типы. В группе подростков с легким когнитивным расстройством (F06.7) достоверно чаще $(p<0,05)$ диагностировался лабильный тип акцентуации характера у мальчиков $(36,9 \% \pm 10,0 \%)$, чем у девочек $(6,25 \% \pm 12,0 \%)$.

Проведенное исследование позволило установить характерологические особенности развития личности и эмоциональных расстройств подростков с ДЦП и прогнозировать их значение в формировании психопатологических нарушений и качества социально-психологической адаптации этих групп пациентов.

Ключевые слова: детский церебральный паралич, подростки, характерологические особенности. 